\title{
Consumer Perception towards Indira Canteen: A Study in Bengaluru
}

\author{
R. Raghupathi, M. J. Anjan kumar* and A. P. Bhavya \\ Department of Agricultural Economics, University of Agricultural Sciences, \\ GKVK Bengaluru, India \\ *Corresponding author
}

\section{A B S T R A C T}

\section{Keywords}

Food security, Indira canteen, unorganised sector, Saving, Nutritional security and Urban poor

Article Info

Accepted: 20 October 2020 Available Online: 10 November 2020
Food security has been a matter of concern in due to the global food crisis and rising food prices. For the urban poor, access to food is low due to high unorganized or informal sector employment which fetches low as well as irregular income. A major concern of any Government today is to avert deprivation and find some sustainable livelihood opportunities for the most neglected sections of the society. Government of Karnataka introduced Indira canteens, a chain of fast food joints for the urban poor to mitigate food insecurity in Bengaluru managed by BBMP. Our sample size consist of 30 respondents at different Indira canteen of which 66.66 per cent of respondents are at the age of 26-40 and more than 66.00 per cent are male respondents. Majority of the of the respondents ( 90 per cent) are educated at below metric level and 96.66 per cent of respondents are working in unorganised sector's like street vendors, taxi drivers, daily labours, construction workers and security guards. Two out of every three respondents have monthly income of less than Rs.10000. 76.67 per cent of the respondents opined that the food supplying is of sufficient quantity to eat at the Indira canteens. And also majority of the respondents (28/30) opined that the food supplying is of above average and good quality. Two out of every three respondents visit Indira canteens daily for their food need. Average daily savings due to setting up of Indira canteen 78.66 per cent over the previous expenditure of food security and of which 66.66 per cent of the saved money is being utilized for spending on sufficient quantities of fruits, vegetables and milk, which will improve the food and nutritional security. Remaining saved money is being utilized for medical, education and other needs, which would improve the socio-economic status of the urban poor.

\section{Introduction}

Food security has been a matter of concern in due to the global food crisis and rising food prices. For the urban poor, access to food is low due to high unorganized or informal sector employment which fetches low as well as irregular income. A major concern of any Government today is to avert deprivation and find some sustainable livelihood opportunities for the most neglected sections of the society. Government of Karnataka introduced Indira canteens, a chain of Fast food joints for the urban poor to mitigate food insecurity in Bengaluru managed by BBMP. But millions of people here are construction workers, auto rickshaw drivers and barbers who do not have enough money. Indira Canteen was fed by 
these people at a lower price. According statistics says that $28 \%$ children (below 5 years) in Bengaluru are underweight while $13 \%$ women and $10 \%$ men in the city don't get adequate nutrition.

Compared to other states the number of people day who can't afford two meals a day is more here. This is because Indira canteen passed here. As the tender notification for food catering services notified by BBMP, about 10 companies participated in the bidding process and five were shortlisted. Rewards, an NGO had the lowest bid, so it was given five constituencies. Of the others, only Chef Talk was willing to match the bid, so BBMP decided to give them additional constituencies.

Chef Talk Food \& Hospitality Services Private Limited, Head office located in Mumbai and the regional offices are located at Bengaluru, Pune and Hyderabad. It will cater the food to all the Indira canteens except the Indira canteens located in 5 Assembly constituencies. Rewards, an NGO Head office located New Delhi and regional office located in Bengaluru and other few cities, supplying the catering services to remaining Indira canteens located in 5 Assembly constituencies.

This experiment designed with the objective of providing food to "Poorest of the poor". This project has started on a pilot basis, in the first phase, 101 canteens are opened to the public serving breakfast at Rs 5 per plate and Rs 10 for meals during afternoon and night.

\section{Materials and Methods}

The researcher has done a descriptive research to study the Perception of consumers towards Indira canteen. Convenience sampling technique has been used and the primary data were collected through well- structured questionnaire. Secondary data were collected from the available records, websites etc. The data has been analysed with the statistical Tools like percentage analysis. Tabular analysis and Budget techniques used for analysis of impact on Indira canteen on individual's food security.

\section{Results and Discussion}

The table 1 shows that most of the respondents belong to the age group between 26 to 40 years, $67 \%$ are male, $33 \%$ are female, occupation level $40 \%$ of the respondent's labours, $26.67 \%$ of the respondent's drivers, education level $36.67 \%$ of the respondent's primary school (1-7), $26.67 \%$ of the respondents both illiterate and high school (8-10), marital status $80 \%$ of the respondents are married, $20 \%$ of the respondents are unmarried and most of the respondents' income level is between Rs.5000 -10000 .

The table 2 shows that $100 \%$ of the respondents are fully aware about the low price level at Indira canteen

The table 3 shows that 76.67 per cent of the respondents opined that they are supplying sufficient quantity of food to eat to the Indira canteen visitors $16.67 \%$ of the respondents no opined and also $6.67 \%$ of the respondents are disagree of the sufficient quantity of food is being provided at Indira canteen.

The table 4 shows that 76.67 per cent of the respondents opined that they are supplying average taste of food in the Indira canteen $16.67 \%$ of the respondent's opined good taste of the food and $6.67 \%$ respondents are in poor taste of food in the Indira canteen.

The table 4 shows that 76.67 per cent respondents claim that they are satisfying the taste of food at the Indira Cantonese, with 
16.67per cent of the respondents having a good taste of food and 6.67 per cent talented canteen of food in Indira.

The table 5 shows that $66.67 \%$ of the respondents daily, $26.67 \%$ of the respondents weekly and also $6.67 \%$ of the respondents visit in to the Indira canteen is monthly (Fig. 1 and 2).

Table.1 Personal details of the respondents

\begin{tabular}{|c|c|c|c|}
\hline Sl.No. & Particulars & No. of respondents & Percentage to the total \\
\hline 1. & Age(year) & & \\
\hline a) & $0-25$ & 5 & 16.67 \\
\hline b) & $26-40$ & 20 & 66.67 \\
\hline \multirow[t]{2}{*}{ c) } & $41-60$ & 5 & 16.66 \\
\hline & Total & 30 & 100 \\
\hline 2. & Family Type & & \\
\hline a) & Nuclear & 24 & 80 \\
\hline \multirow[t]{2}{*}{ b) } & Joint & 6 & 20 \\
\hline & Total & 30 & 100 \\
\hline 3. & Gender & & \\
\hline a) & Male & 20 & 66.67 \\
\hline \multirow[t]{2}{*}{ b) } & Female & 10 & 33.33 \\
\hline & Total & 30 & 100 \\
\hline 4. & Education Level & & \\
\hline a) & Illitrirate & 8 & 26.67 \\
\hline b) & Primary(1-7) & 11 & 36.67 \\
\hline c) & High school(8-10) & 8 & 26.67 \\
\hline \multirow[t]{2}{*}{ d) } & College and above $(<10)$ & 3 & 10 \\
\hline & Total & 30 & 100 \\
\hline 5. & Occupation Level & & \\
\hline a) & Labours & 12 & 40 \\
\hline b) & Driver & 8 & 26.67 \\
\hline c) & Security & 5 & 16.67 \\
\hline d) & Vendors & 4 & 13.33 \\
\hline \multirow[t]{2}{*}{ e) } & Student & 1 & 3.33 \\
\hline & Total & 30 & 100 \\
\hline 6. & Marital Status & & \\
\hline a) & Married & 24 & 80 \\
\hline \multirow[t]{2}{*}{ b) } & Unmarried & 6 & 20 \\
\hline & Total & 30 & 100 \\
\hline 7. & Monthly Income Level & & \\
\hline a) & $<5000$ & 7 & 23.33 \\
\hline b) & $6000-10000$ & 13 & 43.33 \\
\hline c) & $11000-15000$ & 8 & 26.67 \\
\hline \multirow[t]{2}{*}{ d) } & $>15000$ & 2 & 6.67 \\
\hline & Total & 30 & 100 \\
\hline
\end{tabular}

Source: Primary data 
Table.2 Awareness of the respondents towards the low price level at Indira canteen

\begin{tabular}{|c|c|c|}
\hline Awareness & No. Of respondents & Percentage to the total \\
\hline a) Fully aware & 30 & 100 \\
\hline b) partially aware & - & - \\
\hline c) Somewhat aware & - & - \\
\hline d) Not at all & - & - \\
\hline Total & 30 & 100 \\
\hline
\end{tabular}

Table.3 Opinion towards the sufficient quantity of food provided at Indira canteen at the lowest price

\begin{tabular}{|c|c|c|c|}
\hline Opinion & & No. Of respondents & Percentage to the total \\
\hline & Agree & 23 & $\mathbf{7 6 . 6 7}$ \\
\hline b) & No opinion & 5 & 16.67 \\
\hline c) & Disagree & 2 & 6.67 \\
\hline & TOTAL & 30 & 100 \\
\hline
\end{tabular}

Table.4 Opinion towards the 'good' taste of food types provided at Indira canteen

\begin{tabular}{|c|c|c|}
\hline Opinion & No. Of respondents & Percentage to the total \\
\hline a) Good & 5 & 16.67 \\
\hline b) Average & 23 & 76.67 \\
\hline c) Poor & 2 & 6.67 \\
\hline Total & 30 & 100 \\
\hline
\end{tabular}

Table.5 How often you visit Indira canteen

\begin{tabular}{|c|c|c|}
\hline Visit & No. Of respondents & Percentage to the tota \\
\hline a) Daily & 20 & 66.67 \\
\hline b) Weekly & 8 & 26.67 \\
\hline c) Monthly & 2 & 6.67 \\
\hline d) Yearly & - & - \\
\hline Total & 30 & 100 \\
\hline
\end{tabular}

Table.6 Expenditure on meals before and after Indira canteen (per day)

\begin{tabular}{|c|c|c|c|c|}
\hline Particulars & \multicolumn{2}{|c|}{ Before Indira canteen } & \multicolumn{2}{|c|}{ After Indira canteen } \\
\hline Meals per day & $\begin{array}{c}\text { No. Of } \\
\text { respondents }\end{array}$ & $\begin{array}{c}\text { Percentage to } \\
\text { the total }\end{array}$ & $\begin{array}{c}\text { No. Of } \\
\text { respondents }\end{array}$ & $\begin{array}{c}\text { Percentage to the } \\
\text { total }\end{array}$ \\
\hline A. One & - & - & 2 & $\mathbf{6 . 6 7}$ \\
\hline B. Two & 11 & 36.67 & 10 & $\mathbf{3 3 . 3 3}$ \\
\hline C. Three & 19 & 63.33 & 18 & $\mathbf{6 0}$ \\
\hline Total & 30 & 100 & 30 & $\mathbf{1 0 0}$ \\
\hline $\begin{array}{c}\text { Average Daily Savings Due } \\
\text { To Indira Canteen(Rs) }\end{array}$ & & $\mathbf{7 8 . 6 6}$ & & $\mathbf{2 0 . 8 3}$ \\
\hline
\end{tabular}


Table.7 Expenditure on meals before and after Indira canteen (per day)

\begin{tabular}{|c|c|c|c|c|}
\hline Particulars & \multicolumn{2}{|c|}{ Before Indira canteen } & \multicolumn{2}{|c|}{ After Indira canteen } \\
\hline Enough food & $\begin{array}{c}\text { No. Of } \\
\text { respondents }\end{array}$ & $\begin{array}{c}\text { Percentage to the } \\
\text { total }\end{array}$ & $\begin{array}{c}\text { No. Of } \\
\text { respondents }\end{array}$ & $\begin{array}{c}\text { Percentage to the } \\
\text { total }\end{array}$ \\
\hline a) Yes & 12 & 40 & 11 & $\mathbf{3 6 . 6 7}$ \\
\hline b) No & 18 & 60 & 19 & $\mathbf{6 3 . 3 3}$ \\
\hline TOTAL & $\mathbf{3 0}$ & $\mathbf{1 0 0}$ & $\mathbf{3 0}$ & $\mathbf{1 0 0}$ \\
\hline
\end{tabular}

Fig.1 Flowchart showing food security through Indira canteens

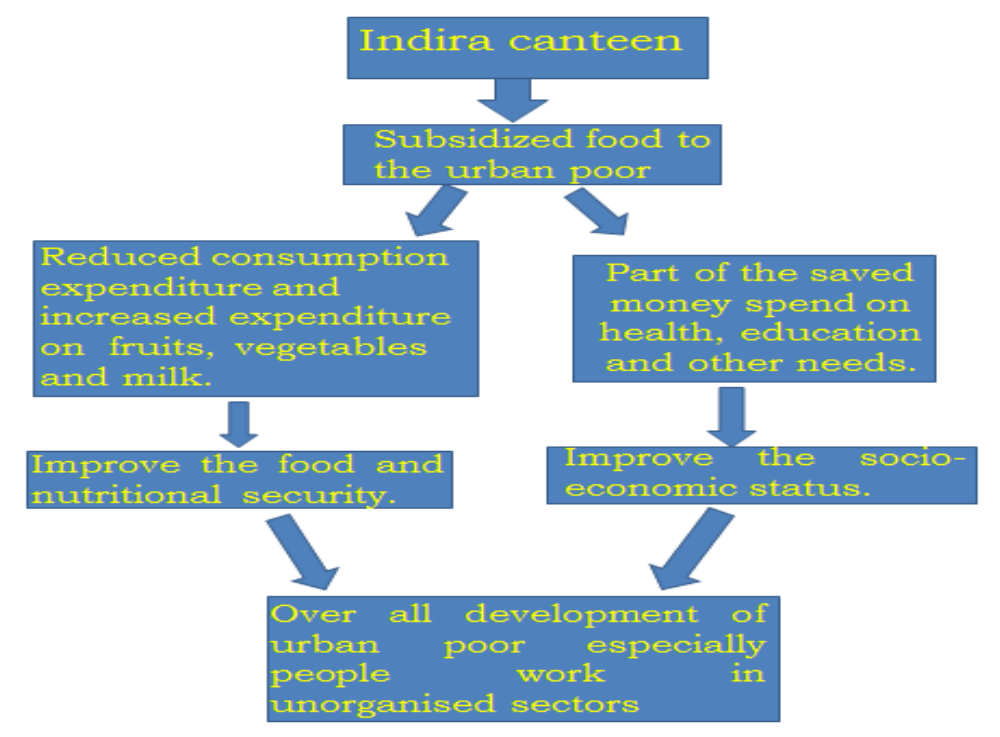

Fig.2 Pie chart showing saved money spent on other different needs

\section{Saved money spent on other needs}

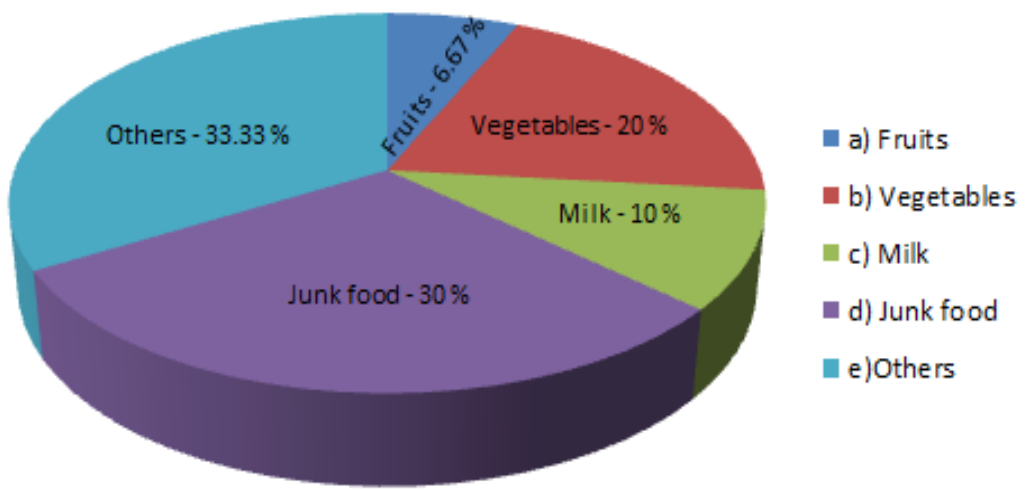

The table 6 shows that $63.33 \%$ of the respondents two times and also $36.67 \%$ of the respondent's expenditure on meals per day before Indira canteen is three times. And also after Indira canteen $60 \%$ of the respondents three time, $33.33 \%$ of the respondents two 
times and also $6.67 \%$ of the respondent's expenditure on meals per day Indira canteen is one time.

The table 7 shows that $60 \%$ of the respondents not meet the enough food for the daily and also $40 \%$ of the respondents meet the food enough daily of the before Indira canteen and also seen the simultaneously after Indira canteen $63.33 \%$ of the respondents not meet the food enough daily and also $36.67 \%$ of the respondents meet the food enough daily after Indira canteen.

The table 6 shows that $33.33 \%$ of the respondents expenditure saving money for the others purpose like medical expenses, saving, education, watching movies and personal consumptions, $30 \%$ of the respondents are expenditure on junk foods, $20 \%$ of the respondents expenditure on vegetables, $10 \%$ of the respondents expenditure on milk and also $6.67 \%$ of the respondents expenditure on fruits.

\section{Conclusion}

Two in every three people working in unorganized sector visit Indira canteen daily, which shows the food insecurity to the urban poor and Indira canteen, is trying to address it.

Average Daily expenditure before setting up of Indira canteen was Rs. 78.66 per day and after setting up of Indira canteen, the expenditure on food is reduced to Rs. 20.83 per day. So, he can save Rs. 57.93 per day, which he can utilized for other necessary needs like fruits, vegetables and milk, which will improve the food and nutritional security.

33.33 per cent of saved money is spent on other needs like health, and education, which will improve the socio-economic status of the urban poor.

\section{References}

Ashok Kumar, A. and Krishnan, D., (2013). Perception of consumers towards "amma unavagum" with special reference to Vellore city, TN, India. International Journal of Research in Business Management. Vol. 1(5); 1722.

BBMP- Anna Bagya. Varun Kumar, M., Balaji M., Narsimmam, M \& Thanveer Ahmed L.R., (2015). The Reach and Impact of Amma Brand Schemes and Products in Tamil Nadu for Public welfare. International Journal of Applied Engineering Research, Vol.10 No. 92

Nithya, A.R., M. Bagyalakshmi, R. Karthick (2018). Linchpins for Sustainability and Scalability of Hotel Industry: Amma Unavagam An Empirical Research, SUMEDHA Journal of Management Vol. 7 No. 2 April - June 2018, pp.160170.

\section{How to cite this article:}

Raghupathi, R., M. J. Anjan kumar and Bhavya, A. P. 2020. Consumer Perception towards Indira Canteen: A Study in Bengaluru. Int.J.Curr.Microbiol.App.Sci. 9(11): 2825-2830. doi: https://doi.org/10.20546/ijcmas.2020.911.342 